\section{IJßER}

ISSN: 2149-5939
International Journal of Social Sciences and Education Research

Online, http://dergipark.gov.tr/ijsser

Volume: 3(1), 2017

\title{
An application to determine the efficacy of emoji use on social mar- keting ads
}

Volkan Yakın ${ }^{1}$

Received Date: 03 / 09 / 2016
Oya $\operatorname{Eru}^{2}$

Accepted Date: 25 / 12 / 2016

\begin{abstract}
Social marketing can be described as non-profit organizations' marketing activities. With social marketing activities, it is aimed to create awareness of the campaign issues for create a useful behavioral pattern in society. As for business organizations, promotion is an important part of marketing activities in nonprofit organizations too. With the usage of the Internet in the marketing area, new channels have emerged to perform promotional activities. Social media can be described as one of these new channels. The most important reason of usage of social media as a promotion channel by nonprofit organizations is the possibility to reach more people on a tight budget. Also, social media provides to create an interactive communication, to measure campaign results and to transmit campaign messages to the right audience. Recently the newest concept using as a promotional tool can be described as emoji. Many companies including nonprofit organizations have started to use emojis in their advertising campaigns. The aim of this Study is to aimed to measure the attitudes towards emoji usage in social marketing campaigns and to guide companies who are going to use emojis in their advertising campaigns in the future. Not to encounter studies about measuring the effectiveness of emojis in marketing literature, expresses the importance of the study. In the study, experimental design method has been used and a survey has been applied to the selected sample. According to the results of the study, it has been concluded that emojis are effective for social advertising campaigns. Participants expressed that, usage of emojis in advertising campaigns is suitable for social campaigns. And using emojis in advertising campaigns explains the Project successfully. They expressed that the transmitted message of campaign is informative and effective. And also participants expressed that these kinds of campaigns are attractive, creative and innovative.
\end{abstract}

Keywords: Social marketing, social media, promotion, emoji

\section{Introduction}

As well as in profit-oriented firms, promotional activities constitute a significant part of marketing activities also in nonprofit firms too. In case, with the Beginning of using in the marketing activities of the Internet, new promotion channels have been emerged. The possibility of reaching the target group everywhere at every moment with the beginning mobile usage of the internet, the growth in smart phone usage and the increase in social media usage has made online environments to become an important promoting tool for nonprofit organizations, especially due to their limited budgets.

Nowadays, the newest concept to be used as promotional tools can be described as emojis. Many organizations around the world, including non-profit organizations, are starting to use emojis in their advertising campaigns. The recognition of emoji as a common language all over the world and being seen as the easiest way to express emotions can be explained as two main reasons why companies use emoji in their promotional campaigns. The aim of this study is to explore

\footnotetext{
${ }^{1}$ Asst. Prof.Dr., Abant Izzet Baysal University, Gerede School of Applied Sciences, BOLU/TURKEY, volkanyakin@gmail.com

${ }^{2}$ Asst. Prof.Dr., Abant Izzet Baysal University, Gerede School of Applied Sciences, BOLU/TURKEY, oyaeru@ibu.edu.tr; oya.eru@gmail.com
} 
Yakın, V., Eru, O. (2017). An application to determine the efficacy of emoji use on social marketing ads.

International Journal of Social Sciences and Education Research, 3(1), 230-240.

attitudes towards nonprofit organizations' advertising campaigns created with emojis and lead to other organizations who are considering using emojis in future advertising campaigns.

\section{Conceptual framework}

The marketing activities of non-profit organizations are evaluated within the scope of "Social Marketing". The concept of social marketing was first described by Kotler and Zaltman (1971). According to this, social marketing; can be defined as "the design, implementation and control of programs influencing the acceptability of social ideas, including product planning, pricing, communication, distribution and marketing research considerations" (Aytekin and 2015 adapted from Kotler and Zaltman). Social marketing tries to influence social behavior for the general benefit of the community (Kotler and Andreasen, 1996). Social marketing also benefits from elements such as sustainability, physical evidence, human, public, partnership, politics and funding as well as marketing mix members (Özcan, 2015, Weinreich, 1999). A significant part of Social Marketing campaigns are promoting activities. According to Kotler and Lee (2011), promotional activities include persuasive communication techniques that emphasize the benefits, features, cost and accessibility of a product or service. These techniques include messaging, news, applications on media channels, and other creative and applicable promotional elements.

With social media, corporations can achieve multi-faceted goals such as establishing individual contacts with the target consumer mass, establishing brand loyalty, transferring corporate message, and creating to the right marketing decisions with consumers' feedbacks (Köksal and Özdemir, 2013). Using social media is an effective way for non-profit organizations' advertising campaigns (Weinreich, 2007). By using social media, companies can reach more people with lower budgets, establish an interactive communication with people, spread campaigns to wider masses, reach the right audience and measure them (Onat and Alikıliç, 2008). The circumstances above, explain why nonprofit organizations can use social media for their marketing campaigns. In addition to this, it can be stated that people start to move away from traditional advertising channels. People are in constant demand for control of media consumption and want to access and display immediately of relevant content which is suitable for them (Mangold and Faulds, 2014). Therefore, when evaluated in this respect, social media can be considered as a more suitable advertising medium for social marketing. The most innovative advertising campaigns created using social media are ad campaigns created with emojis.

Emojis can be described as icons that simply express emotions and thoughts developed by Shigetaka Kurita to reduce restrictions on text messages (Golden, 2015). It is believed that the most important reason why emojis start to be used in advertising campaigns is to be accepted as a common alphabet which means the same thing all over the world and reflect people's emotions. Huang et al. (2008) also state that emojis provide a more enjoyable and positive communication experience and allow personal interaction. Other reasons for using emojis are that a large part of the online population is using emoji and helping to communicate among people Emogi Report (2015). According to the researches carried out, it has been determined that the use of emoji in promotional activities increased by $777 \%$ compared to previous years (Tao, 2016).

\section{Methodology}

Experimental design method has been utilized for the application of the research. For this purpose, it is inspired by WWF digital advertising campaigns. Relevant campaigns have been 
Yakın, V., Eru, O. (2017). An application to determine the efficacy of emoji use on social marketing ads. International Journal of Social Sciences and Education Research, 3(1), 230-240.

redesigned to fit the purpose of the research. In Application part, it is aimed to measure the attitudes towards emoji usage in social marketing campaigns by showing two separate advertising banners to two separeted group. One of the banners used in the research was designed as an advertisement poster asking participants to send tweets with \#helpme hashtag by using emoji and the other banner was also designed to send an SMS by texting HELPME (short message).

The pilot study conducted for this purpose was tested the suitability of the scale to be used in the study. Questionnaires consisting of 27 questions and three chapters were applied to Gerede School of Applied Science students by convenience sampling. There are 686 students in the School of Applied Science. The survey was distributed to 400 students. After unsuitable surveys were taken out, 346 surveys were taken into consideration. Research is limited to students' opinions and questions. The collected data were analyzed by SPSS package program. The findings and the results of the analyzes can be seen below.

\section{Findings}

The findings about the survey can be seen below. There are two groups of participants. First group is consist of participants who answered the questions about SMS advertisement campaign.

\subsection{SMS group}

Table 1 Demographical tata

\begin{tabular}{|l|c|c|l|c|c|}
\hline Gender & F & \% & Department & F & \% \\
\hline Female & 79 & 45,7 & Banking and Finance & 42 & 24,3 \\
\hline Male & 94 & 54,3 & Banking and Finance Evening & 46 & 26,6 \\
\hline Total & 173 & 100,0 & Marketing & 19 & 11,0 \\
\hline Age & F & $\%$ & Marketing Evening & 22 & 12,7 \\
\hline $16-25$ & 173 & 100,0 & International Trade and Logistics & 44 & 25,4 \\
\hline Total & $\mathbf{1 7 3}$ & $\mathbf{1 0 0 , 0}$ & Total & $\mathbf{1 7 3}$ & $\mathbf{1 0 0 , 0}$ \\
\hline
\end{tabular}

It is seen that most of the participants were male students. All of them are between 16-25 age years old. 26,6 of them are students of Banking and Finance Evening department, \%25,4 of them are International Trade and Logistics department students, \%24,3 of them are Banking and Finance students, \%12,7 of the participants are Marketing Evening department students and \%11,0 of them are marketing students.

It can be seen on the table that most of the participants spent time on internet 3-4 hours per day and \%20,8 of them spent time on internet 5-8 hours per day. Most of the students, follow social media 5 year and over. Also it can be seen on the table that $\% 52$ of the students connect to internet via smart phones. Most of the students use their smart phones for connecting to internet. According to the analyzes, it can be said that a large majority of the participants spend 1-3 hours a day on the social media, they have different social media accounts. And most of them ever donate before. 
Yakın, V., Eru, O. (2017). An application to determine the efficacy of emoji use on social marketing ads. International Journal of Social Sciences and Education Research, 3(1), 230-240.

Table 2 The usage of internet and social media

\begin{tabular}{|l|c|c|l|c|c|}
\hline Time spent on Internet & F & $\mathbf{\%}$ & Following Social Media & F & \% \\
\hline Less than 1 hour a day & 13 & 7,5 & Less than 1 year & 14 & 8,1 \\
\hline 1-2 hours per day & 43 & 24,9 & $1-2$ years & 12 & 6,9 \\
\hline 3-4 hours per day & 72 & 41,6 & $3-4$ years & 48 & 27,7 \\
\hline 5-8 hours per day & 36 & 20,8 & 5 year and over & 99 & 57,2 \\
\hline 9-12 hours per day & 9 & 5,2 & Total & 173 & 100,0 \\
\hline Total & 173 & 100,0 & Using mobile phone for & F & $\%$ \\
\hline Connecting device & $\mathrm{F}$ & $\%$ & Speaking & 52 & 30,1 \\
\hline Desktop Computer & 3 & 1,7 & Texting & 31 & 17,9 \\
\hline Laptop & 8 & 4,6 & Connecting to internet & 86 & 49,7 \\
\hline Smart Phone & 90 & 52,0 & Video calling & 4 & 2,3 \\
\hline Tablet & 1 &, 6 & Total & 173 & 100,0 \\
\hline Laptop and smart phone & 68 & 39,3 & $\begin{array}{l}\text { Time spent on social me- } \\
\text { dia }\end{array}$ & F & $\%$ \\
\hline Desktop and smart phone & 3 & 1,7 & Less than 1 hour a day & 33 & 19,1 \\
\hline Total & 173 & 100,0 & $1-3$ hours per day & 95 & 54,9 \\
\hline Social media ownership & $\mathrm{F}$ & $\%$ & $4-6$ hours per day & 38 & 22,0 \\
\hline I just have Facebook account & 15 & 8,7 & Over 7 hours a day & 7 & 4,0 \\
\hline I just have Twitter account & 5 & 2,9 & Total & 173 & 100,0 \\
\hline $\begin{array}{l}\text { I have different social media ac- } \\
\text { counts }\end{array}$ & 153 & 88,4 & Ever donate & F & $\%$ \\
\hline Total & & & & 63 & 36,4 \\
\hline & 173 & 100,0 & Yes & 110 & 63,6 \\
\hline & & & No & 173 & 100,0 \\
\hline
\end{tabular}

\subsection{Emoji group}

The second group of the selected sample is consist of students who answered the questions about Emoji advertisement campaign. And the data about the answers of the Emoji group can be seen below.

Table 3. Demographical data

\begin{tabular}{|l|r|r|l|r|r|}
\hline Gender & \multicolumn{1}{l|}{ F } & \multicolumn{1}{l}{ \% } & Department & F & \multicolumn{1}{l|}{} \\
\hline Female & 91 & 52,6 & Banking and Finance & 49 & 28,3 \\
\hline Male & 82 & 47,4 & Banking and Finance Evening & 40 & 23,1 \\
\hline Total & $\mathbf{1 7 3}$ & $\mathbf{1 0 0 , 0}$ & Marketing & 32 & 18,5 \\
\hline Age & & & Marketing Evening & 8 & 4,6 \\
\hline $16-25$ & 172 & 99,4 & International Trade and Logistics & 30 & 17,3 \\
\hline $26-35$ & 1 &, 6 & $\begin{array}{l}\text { International Trade and Logistics } \\
\text { Evening }\end{array}$ & 14 & 8,1 \\
\hline Total & $\mathbf{1 7 3}$ & $\mathbf{1 0 0 , 0}$ & Total & $\mathbf{1 7 3}$ & $\mathbf{1 0 0 , 0}$ \\
\hline
\end{tabular}

According to the answers of participants, it can be seen that most of them are consist of female students. Most of them are between 16-25 years old. \%28,3 of the students are studying at the Banking and Finance Department, \%23,1 of the students study at Banking and Finance Evening Department, $\% 18,5$ of them study at Marketing Department, $\% 17,3$ of the students study at International Trade and Logistics and \% 8,1 of them study at International Trade and Logistics Evening Department and rest of them study at Marketing Evening Department. 
Yakın, V., Eru, O. (2017). An application to determine the efficacy of emoji use on social marketing ads.

International Journal of Social Sciences and Education Research, 3(1), 230-240.

Table 4 Usage of internet and social media

\begin{tabular}{|c|c|c|c|c|c|}
\hline Time spent on Internet & $\mathbf{F}$ & $\%$ & Time spent on social media & $\mathbf{F}$ & $\%$ \\
\hline Less than 1 hour a day & 11 & 6,4 & Less than 1 hour a day & 34 & 19,7 \\
\hline 1-2 hours per day & 42 & 24,3 & 1-3 hours per day & 84 & 48,6 \\
\hline 3-4 hours per day & 62 & 35,8 & 4-6 hours per day & 41 & 23,7 \\
\hline 5-8 hours per day & 45 & 26,0 & Over 7 hours a day & 14 & 8,1 \\
\hline 9-12 hours per day & 13 & 7,5 & Total & 173 & 100,0 \\
\hline Total & 173 & 100,0 & Social media ownership & $\mathbf{F}$ & $\%$ \\
\hline Connecting Device & $\mathrm{F}$ & $\%$ & I just have Facebook account & 23 & 13,3 \\
\hline Laptop & 10 & 5,8 & I just have Twitter account & 5 & 2,9 \\
\hline Tablet & 1 & ,6 & $\begin{array}{l}\text { I have different social media ac- } \\
\text { counts }\end{array}$ & 131 & 75,7 \\
\hline Mobile Phone & 99 & 57,2 & I have no social media account & 14 & 8,1 \\
\hline Laptop and mobile phone & 63 & 36,4 & Total & 173 & 100,0 \\
\hline Total & 173 & 100,0 & Using emoji in text messaging & $\mathrm{F}$ & $\%$ \\
\hline Following social media & $\mathbf{F}$ & $\%$ & Yes & 166 & 96,0 \\
\hline Less than 1 year & 11 & 6,4 & No & 7 & 4,0 \\
\hline $1-2$ years & 11 & 6,4 & Total & 173 & 100,0 \\
\hline 3-4 years & 58 & 33,5 & $\begin{array}{l}\text { Frequency of using emoji in text } \\
\text { messaging }\end{array}$ & $\mathrm{F}$ & $\%$ \\
\hline 5 year and over & 93 & 53,8 & $\begin{array}{l}\text { Very Frequently (in almost every } \\
\text { text) }\end{array}$ & 47 & 27,2 \\
\hline Total & 173 & 100,0 & Frequently (in most texts) & 60 & 34,7 \\
\hline Reasons of using emojis & $\mathbf{F}$ & $\%$ & Sometimes (in a couple of texts) & 49 & 28,3 \\
\hline $\begin{array}{l}\text { Expressing my feelings bet- } \\
\text { ter }\end{array}$ & 75 & 43,4 & Rarely (only a few texts) & 10 & 5,8 \\
\hline $\begin{array}{l}\text { For a simple and fast com- } \\
\text { munication }\end{array}$ & 24 & 13,9 & Never & 7 & 4,0 \\
\hline $\begin{array}{l}\text { For Innovative communica- } \\
\text { tion }\end{array}$ & 1 & 6 & Total & 173 & 100,0 \\
\hline Global language & 3 & 1,7 & $\begin{array}{l}\text { Emojis make text messages better } \\
\text { to understand }\end{array}$ & $\mathbf{F}$ & $\%$ \\
\hline $\begin{array}{l}\text { Expressing better and sim- } \\
\text { ple }\end{array}$ & 40 & 23,1 & Yes & 148 & 85,5 \\
\hline Express better and global & 7 & 4,0 & No & 7 & 4,0 \\
\hline $\begin{array}{l}\text { Express better and innova- } \\
\text { tive }\end{array}$ & 12 & 6,9 & Not sure & 18 & 10,4 \\
\hline Simple and innovative & 4 & 2,3 & Total & 173 & 100,0 \\
\hline I don't use emoji & 7 & 4,0 & Ever donate & $\mathbf{F}$ & $\%$ \\
\hline \multirow[t]{3}{*}{ Total } & 173 & 100,0 & Yes & 59 & 34,1 \\
\hline & & & No & 114 & 65,9 \\
\hline & & & Total & 173 & 100,0 \\
\hline
\end{tabular}

According to the data above, it can bee said that, $\% 35,8$ of the participants spent $1-3$ hours on internet per day and \%26 of them spent 5-8 hours on internet per day. Most of the students also spent 1-3 hour per day on social media. Like other group, students who called as emoji group 
Yakın, V., Eru, O. (2017). An application to determine the efficacy of emoji use on social marketing ads. International Journal of Social Sciences and Education Research, 3(1), 230-240.

mostly use their smart phones to connect internet $(\% 57,2)$. Most of them follow social media 5 year and over and most of them have different social media accounts. When it is asking that if they use emoji in text messaging, $\% 96$ of them stated that they use emojis in text messaging. Also they stated that they use emojis in text messaging frequently. And when looked at the data, students stated that emojis help to express their feelings better. And they stated that emojis are the simplest and fastest way of communication. \%85,5 of the students expressed that emojis make text messages better to understand. According to the data, $\% 65,9$ of the students also ever donate too.

\subsection{Mean and standard deviation}

For measure the attitudes towards to advertisement message, 13 expressions asked to the participants. The mean and standart deviation of the participants' answers can be seen below.

Table 5 Attitudes towards to advertisement message

\begin{tabular}{|l|c|c|c|c|}
\hline & \multicolumn{2}{|c|}{ SMS Group } & \multicolumn{2}{c|}{ Emoji Group } \\
\hline Attitude Expressions & Mean & S.deviation & Mean & S.deviation \\
\hline $\begin{array}{l}\text { I think all social campaigns should be made in this } \\
\text { style }\end{array}$ & 3,5376 & 1,0756 & 3,8324 & 1,00620 \\
\hline $\begin{array}{l}\text { I think this message is appropriate for the social cam- } \\
\text { paign }\end{array}$ & 3,7803 & 0,93278 & 4,0289 & 0,91135 \\
\hline This campaign is explaining the project successfully & 3,6243 & 1,04708 & 3,8150 & 0,97671 \\
\hline I influenced by this message & 3,2775 & 1,12240 & 3,6705 & 1,01792 \\
\hline I think this campaign is informative & 3,7457 & 1,04216 & 3,9653 & 0,95781 \\
\hline $\begin{array}{l}\text { This message is a helpful message in terms of de- } \\
\text { scribing the campaign }\end{array}$ & 3,7688 & 0,96072 & 4,0462 & 0,81280 \\
\hline I like this style campaigns for social cases & 3,6243 & 1,10121 & 3,9422 & 0,99832 \\
\hline This message encourages me to donate & 3,1908 & 1,21211 & 3,6474 & 1,15005 \\
\hline This campaign is a good campaign. & 3,7514 & 1,09521 & 4,1098 & 0,88565 \\
\hline This campaign is an interesting campaign & 3,4162 & 1,08380 & 3,8208 & 0,99839 \\
\hline The message given by the campaign is clear & 3,9364 & 0,99505 & 4,1908 & 0,89801 \\
\hline The campaign is an innovative campaign & 3,3006 & 1,02404 & 4,0925 & 0,82307 \\
\hline \hline The campaign is a creative campaign. & 3,1445 & 1,08206 & 4,0 & 0,81123 \\
\hline $\mathbf{N}: \mathbf{3 4 6}$ & $* 1$. Strongly Disagree & $\mathbf{5}$ Strongly Agree \\
\hline
\end{tabular}

According to the data above, it can be said that students find emoji campaign more interesting, more innovative and creative. Also according to the results, when the two groups are compared, the students whose advertisement campaign banner about emojis find the advertisement messages clearer, think that all social campaigns should be made in this style, This message is a helpful message in terms of describing the campaign. Also they influenced more than other group.

\subsection{Hypotheses and results of hypothesis tests}

5 basic hypotheses for the research were identified. Hypotheses were analyzed by SPSS sowtware program. The developed hypotheses and the analysis results are as follows. 
Yakın, V., Eru, O. (2017). An application to determine the efficacy of emoji use on social marketing ads.

International Journal of Social Sciences and Education Research, 3(1), 230-240.

H0-1a The attitudes of the students towards the emoji campaign do not differ according to their gender

$\mathrm{H}-1 \mathrm{a}$ The attitudes of the students towards the emoji campaign differ according to their gender

Table 6 Results of H1a

\begin{tabular}{|l|l|l|l|l|l|}
\hline & $\mathrm{N}$ & Mean & S.deviation & $\mathrm{t}$ value & $\mathrm{p}$ value \\
\hline Female & 91 & 3,9606 &, 69593 & & \\
\cline { 1 - 5 } Male & 82 & 3,8882 &, 65945 & 0,701 & 0,485 \\
\hline
\end{tabular}

According to the table, it can bee seen that there is no difference about the attitudes according to gender.

H0-1b The attitudes of the students towards the SMS campaign do not differ according to their gender

$\mathrm{H}-1 \mathrm{~b}$ The attitudes of the students towards the SMS campaign differ according to their gender

Table 7 Results of $\mathrm{H} 1 \mathrm{~b}$

\begin{tabular}{|l|l|l|l|l|l|}
\hline & $\mathrm{N}$ & Mean & S.deviation & $\mathrm{t}$ value & $\mathrm{p}$ value \\
\cline { 1 - 4 } Female & 79 & 3,6816 &, 74922 & & \multirow{2}{*}{2,062} \\
\cline { 1 - 3 } & 94 & 3,4321 &, 82734 & 2,041 \\
\hline
\end{tabular}

According to the table, it can be said that there is a difference about the attitudes of the students according to gender.

H0-2a The attitudes of students towards the emoji campaign do not differ significantly according to whether they previously donated for a social campaign.

H-2a The attitudes of students towards the emoji campaign differ significantly according to whether they previously donated for a social campaign.

Table 8 Results of $\mathrm{H} 2 \mathrm{a}$

\begin{tabular}{|c|c|c|c|c|c|}
\hline & $\mathrm{N}$ & Mean & S.deviation & $\mathrm{t}$ value & $\mathrm{p}$ value \\
\hline Female & 59 & 4,0071 & 63696 & \multirow[b]{2}{*}{1,128} & \multirow[b]{2}{*}{0,261} \\
\hline Male & 119 & 3,8845 & ,69717 & & \\
\hline
\end{tabular}

According to the table, it can be said that there is no differences whether they previously donate for a social campaign.

H0-2b The attitudes of students towards the SMS campaign do not differ significantly according to whether they previously donated for a social campaign.

$\mathrm{H}-2 \mathrm{~b}$ The attitudes of students towards the SMS campaign differ significantly according to whether they previously donated for a social campaign.

Table 9 Results of $\mathrm{H} 2 \mathrm{~b}$

\begin{tabular}{|l|l|l|l|l|l|}
\hline & $\mathrm{N}$ & Mean & S.deviation & $\mathrm{t}$ value & $\mathrm{p}$ value \\
\hline Female & 63 & 3,4676 &, 90262 & & \\
\cline { 1 - 4 } Male & 110 & 3,5909 &, 73568 & $-0,975$ & 0,331 \\
\hline
\end{tabular}

According to the results, it can be said that there is no differences whether they previously donate for a social campaign.

H0-3a The attitudes of the students towards the emoji campaign do not differ according to the time they spent in social media.

$\mathrm{H}-3 \mathrm{a}$ The attitudes of the students towards the emoji campaign differ according to the time they spent in social media. 
Yakın, V., Eru, O. (2017). An application to determine the efficacy of emoji use on social marketing ads. International Journal of Social Sciences and Education Research, 3(1), 230-240.

Table 10 Results of $\mathrm{H} 3 \mathrm{a}$

\begin{tabular}{|l|c|c|c|c|}
\hline & N & Mean & F Value & p Value \\
\hline Less than 1 hour a day & 34 & 3,7206 & 2,439 & 0,066 \\
\cline { 1 - 3 } 1-3 hours a day & 84 & 3,8929 & & \\
\cline { 1 - 3 } 4-6 hours a day & 41 & 4,1037 & & \\
\cline { 1 - 3 } More than 7 hours a day & 14 & 4,1071 & & \\
\cline { 1 - 3 } Total & 173 & & & \\
\hline
\end{tabular}

$\mathrm{P}$ value is bigger than 0,05 so it can be said that there is no difference according to time spent on social media.

H0-3b The attitudes of students towards SMS campaign do not differ according to the time they spent in social media

$\mathrm{H}-3 \mathrm{~b}$ The attitudes of students towards SMS campaign differ according to the time they spent on social media

Table 11 Results of $\mathrm{H} 3 \mathrm{~b}$

\begin{tabular}{|l|c|c|c|c|}
\hline & N & Mean & F Value & p Value \\
\hline Less than 1 hour a day & 33 & 3,5664 & 0,474 & 0,701 \\
\cline { 1 - 3 } 1-3 hours a day & 95 & 3,5749 & & \\
\cline { 1 - 3 } 4-6 hours a day & 38 & 3,5182 & & \\
\cline { 1 - 2 } More than 7 hours a day & 7 & 3,2088 & & \\
\cline { 1 - 3 } Total & 173 & 3,5460 & & \\
\hline
\end{tabular}

According to the results, it can be seen that there is no difference time spent on social media.

H0-4a The attitudes of students towards the emoji campaign do not differ according to the time they spend online

$\mathrm{H}-4 \mathrm{a}$ The attitudes of students towards the emoji campaign differ according to the time they spend online

Table 12 Results of H4a

\begin{tabular}{|l|c|c|c|c|}
\hline & N & Mean & F Value & p Value \\
\hline Less than 1 hour a day & 11 & 3,5909 & \multirow{2}{*}{1,238} & 0,297 \\
\cline { 1 - 3 } 1-2 hours a day & 42 & 3,9464 & & \\
\cline { 1 - 3 } 3-4 hours a day & 62 & 3,9825 & & \\
\cline { 1 - 3 } 5-8 hours a day & 45 & 3,8519 & & \\
\cline { 1 - 2 } 9-12 hours a day & 13 & 4,1346 & & \\
\hline Total & 173 & & & \\
\hline
\end{tabular}

According to the results, it can be seen that there is no difference according to the time students spent online.

H0-4b The attitudes of students towards the sms campaign differ according to the time they spend online.

$\mathrm{H}-4 \mathrm{~b}$ The attitudes of students towards the sms campaign differ according to the time they spend online. 
Yakın, V., Eru, O. (2017). An application to determine the efficacy of emoji use on social marketing ads. International Journal of Social Sciences and Education Research, 3(1), 230-240.

Table 13 Results of $\mathrm{H} 4 \mathrm{~b}$

\begin{tabular}{|l|c|c|c|c|}
\hline & N & Mean & F Value & p Value \\
\hline Less than 1 hour a day & 13 & 3,5385 & \multirow{2}{*}{1,194} & 0,315 \\
\cline { 1 - 3 } 1-2 hours a day & 43 & 3,6547 & & \\
\cline { 1 - 3 } 3-4 hours a day & 72 & 3,5566 & & \\
\cline { 1 - 3 } 5-8 hours a day & 36 & 3,5299 & & \\
\hline 9-12 hours a day & 9 & 3,0171 & & \\
\hline Total & 173 & & & \\
\hline
\end{tabular}

According to the table, it can be said that there is no difference according to the time they spend online.

H0-5 There is no significant difference in the attitudes of students towards emoji and SMS campaigns.

H-5 There is a significant difference in the attitudes of students towards emoji and SMS campaigns.

Table 14 Results of H5

\begin{tabular}{|l|l|l|l|l|l|}
\hline & $\mathrm{N}$ & Mean & S.deviation & $\mathrm{t}$ value & $\mathrm{p}$ value \\
\hline Emoji Attitude & 173 & 3,9263 &, 67789 & & \\
\cline { 1 - 4 } SMS Attitude & 173 & 3,5460 &, 80012 & 4,880 & 0,000 \\
\hline
\end{tabular}

According to the table, there is a significance difference in the attitudes of students towards emoji and SMS campaigns.

\section{Conclusion}

As a result of the studies carried out in other disciplines related to emoji, there are findings that, such as the fact that people perceive the expressions in emojis as real human emotions and that emojis are the simplest and fastest way to express emotions (Golden, 2015) (Churches et al., 2014).

Although the use of emojis in digital marketing in similar researches is increasing day by day, the fact that no studies were found in the marketing literature to determine its effectiveness has been the most decisive factor in the realization of this research. According to the results of the research, it was determined that there is a meaningful difference between the attitudes of the students towards the emoji advertisement campaign and the attitudes towards the SMS advertisement campaign. Students expressed that they found the advertising campaign created by using emoji more creative and innovative. The use of social media by profit-oriented or non-profit organizations like people is increasing day by day. Through social networks, hundreds of thousands of people interact at any moment. Therefore, using social media to reach customers, followers, volunteers or donors has become an important tool.

Today, social networks can be expressed as the simplest and fastest spreading of information. From here, it would be appropriate for companies or non-profit organizations to use social media to reach the target audience for promotional campaigns Created campaigns reach more people and with lower costs thanks to social media. Also, thanks to social media, awareness and recognition of institutions, products or brands is increasing. 
Yakın, V., Eru, O. (2017). An application to determine the efficacy of emoji use on social marketing ads. International Journal of Social Sciences and Education Research, 3(1), 230-240.

Another benefit provided by social media is to encourage followers to become participants. The use of appropriate emojis in the messages that will be given in the social media campaigns will support the campaign message.

The most important features of emojis are that they can reflect emotions and pass those emotions to the other side. If visual content is often thought to leave a greater emotional impact than words, the benefits of adding emoji to campaign messages can be understood. It is believed that the results obtained with this study will lead to non-profit organizations when it is observed that non-profit organizations often use social media marketing due to their low marketing budget. Nonprofit organizations that want to build an interactive relationship with donors or volunteers can benefit from emojis on the digital footsteps of their campaigns when they design an innovative, sincere campaign. A large part of the participants in the survey stated that they did not donate. When the age ranges of the participants are taken into account, it can be said that they are the group with the most use of social media and emojis because they are in the $\mathrm{Z}$ genaration. Therefore, incorporating emojis into digital campaign messages can help organizations to reach young people, trigger them to donate and make them volunteer members. Emojis will also make campaign messages of non-profit-making organizations world-wide, since they are perceived as a universal language.

This study examined the attitudes of non-profit organizations to use emoji in their advertising campaigns. In other studies, different researches on the use of emoji for profit-oriented companies can be carried out.

\section{References}

Aytekin, P., and Yakın, V. (2015). Duygusal ve Rasyonel Sosyal Reklam Mesajlarının Etkililiği Üzerine Bir Araştırma. Journal of the Institute of Social Sciences Cankiri Karatekin University/Cankiri Karatekin Üniversitesi Sosyal Bilimler Enstitusu Dergisi, 6(1).

Churches, O., Nicholls, M., Thiessen, M., Kohler, M., Keage, H. (2014). $\quad$ Emoticons in Mind: An Event-related Potential Study. Social Neuroscience, 9(2), 196-202.

Faulds, D. J., \& Mangold, W. G. (2014). Developing a Social Media and Marketing Course. Marketing Education Review, 24(2), 127-144.

Golden L. (2015). Emoji History: The Background, History, and Future of The Symbols That Have Taken Over Conversation All Over TheWorld. https://storify.com/lindsaygolden/emojis-history

Huang, A. H., Yen, D. C., \& Zhang, X. (2008). Exploring the Potential Effects of Emoticons. Information \& Management, 45(7), 466-473.

Kotler, P., and Zaltman, G. (1971). Social marketing: An Approach to Planned Social Change. The Journal of Marketing, 3-12.

Kotler, P. and Andreasen, A.R., (1996). Strategic Marketing for Nonprofit Organisations. 5th Ed., Prentice Hall, Upper Saddle River.

Köksal, Y., and Özdemir, Ş. (2013). Bir İletişim Aracı Olarak Sosyal Medya'nın Tutundurma Karması İçerisindeki Yeri Üzerine Bir İnceleme. Süleyman Demirel Üniversitesi İktisadi ve İdari Bilimler Fakültesi Dergisi, 18(1).

Lee, N. R., and Kotler, P. (2011). Social marketing: Influencing behaviors for good. Sage.

Onat, Y. D. D. F., \& Alikılıç, Ö. A. (2008). Sosyal Ağ Sitelerinin Reklam ve Halkla İlişkiler Ortamları Olarak Değerlendirilmesi. Journal Of Yaşar University, 3(9), 1111-1143. 
Yakın, V., Eru, O. (2017). An application to determine the efficacy of emoji use on social marketing ads. International Journal of Social Sciences and Education Research, 3(1), 230-240.

Özcan, B. Ö. (2015). Sosyal Pazarlama Örneği Olarak “Sudaki Ayak İzim” Kampanyası Web Tasarımının Biçim ve İçerik Açısından İncelenmesi. NWSA: Fine Arts, 9(5), 11-21.

Tao, J. (2016). Emojis Are Now Used in 777\% More Campaigns Than Last Year https://blog.appboy.com/emojis-used-in-777-more-campaigns/

Weinreich, N. K. (1999). Hands on social marketing: A step by step guide. Thousand Oaks, CA: Sage.

Weinreich, N. K., (2007), What Is Social Marketing?, Usa: Weinreich Communications.

2015 Emoji Report http://emogi.com/documents/Emoji_Report_2015.pdf 